\title{
African earthen structures in colonial Louisiana: architecture from the Coincoin plantation (1787-1816)
}

\author{
Kevin C. MacDonald ${ }^{1} \&$ David W. Morgan ${ }^{2}$
}

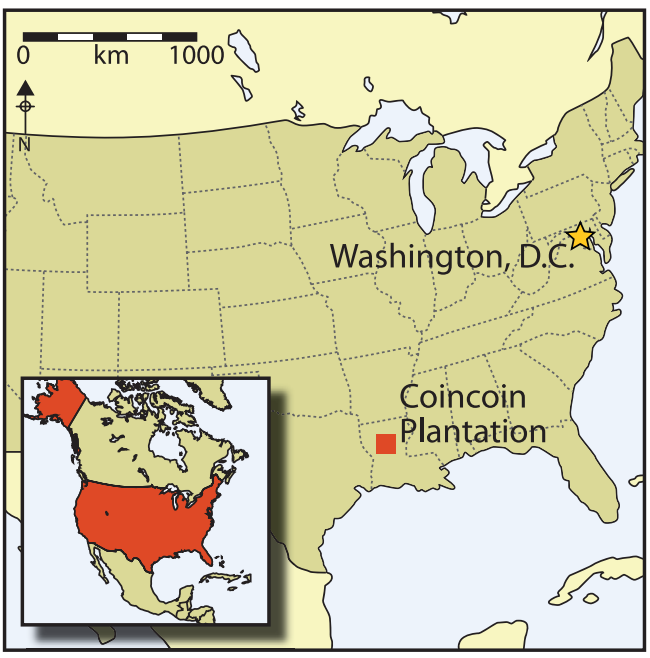

Keywords: USA, Louisiana, eighteenth century, earthen architecture, plantations, slavery born a slave, became the concubine of a French planter, Pierre Metoyer, bore him ten children, and in 1787 was settled by him on a plantation of her own. Locating and excavating her house, the authors discovered it to be a type of claywall building known from West Africa. The house, together with an adjacent clay boundary wall, was probably built by slaves of Bight of Biafra origin loaned from the neighbouring plantation of her ex-partner. These structures are witness to emerging initiatives and interactions among people of African descent-but different African origins - in eighteenth-century Louisiana.

Coincoin, probably of Kongo parentage, was

\section{Introduction}

North American plantation archaeology, since its inception in the late 1960s, has largely concentrated on the East Coast, with some outlying studies in the sugar planting areas of the Gulf Coast (Singleton \& Bograd 1995: 22). The archaeology of the interior of French colonial Louisiana has been comparatively neglected and with it some surprising material aspects of a creolised frontier society. One such aspect is that of the local earthen architecture and questions concerning its derivation from European and/or African sources (Edwards 1994, 2002, 2006). Our current research at a unique colonial-era plantation in north-western Louisiana—owned by a woman of African descent—provides new evidence concerning West African technological contributions to the wider corpus of Creole architecture.

1 UCL Institute of Archaeology, 31-34 Gordon Square, London WC1H OPY, UK (Email: kevin.macdonald@ucl.ac.uk)

2 Southeast Archeological Center, National Park Service, 2035 E. Paul Dirac Drive, Johnson Building, Suite 120, Tallahassee,FL 32310,USA (Email: David_Morgan@nps.gov) 
Marie-Thérèse Coincoin is one of Louisiana's legendary historical figures. An enslaved African woman who found freedom through a lasting liaison with a French bourgeois, she founded a local land-owning dynasty through her many descendants (see Mills, G. 1977; Mills 2009). Since 2001 we have undertaken a programme of archaeological research on the Cane River properties of Coincoin and her children. In part, the goal of this research has been to document the degree to which plantations owned by individuals of African descent differed in material culture and built environment from French-owned plantations. The initial findings of our work at Melrose plantation are detailed elsewhere (MacDonald et al. 2006a, 2006b; Morgan \& MacDonald 2011). Here we outline the salient aspects of our more recent work at Coincoin's initial plantation, occupied between 1787 and 1816 and featuring earthen constructions with marked West African attributes (Figure 1).

Coincoin was born in Natchitoches in

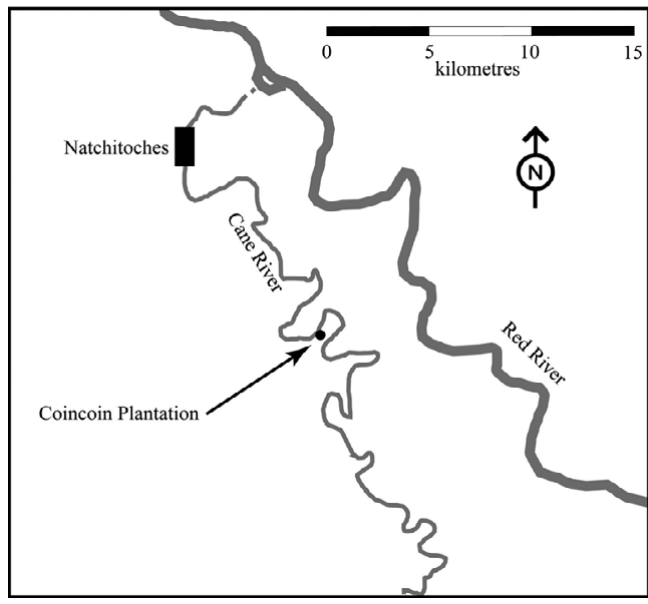

Figure 1. Map showing location of the Coincoin plantation. 1742 to African-born parents, slaves of the post commandant St Denis (Mills 2009). In the past, it has been asserted that she may have been of Glidzi (Ewe, Togo) ancestry, but a current reinvestigation of naming evidence strongly suggests Kongo ancestry for Coincoin and her four siblings. All names find probable matches in Bakongo, including for Coincoin herself'Kwākwana' or 'Kwànkwá' (Roger Blench pers. comm.). In 1766, at the age of 24, she was 'rented' to a wealthy French bachelor, Pierre Metoyer, and became his concubine. Coincoin lived with him for 20 years and together they had 10 children (Mills, G. 1977). Metoyer manumitted Coincoin and she remained with him until shortly before he took a legal wife in 1788 (Mills 2009). This is a critical juncture in the archaeological narrative, because it was at this point, in 1787 , that he gave Coincoin a tract of land, about 67 acres (27ha), adjacent to his own plantation (1787 Natchitoches Census, Mills 1981: 46). So it was at the age of 45 that Coincoin embarked on a new career as a plantation owner.

Sometime shortly after 1790, when tax records show she owned no slaves, Coincoin appears to have acquired a small labour force to help work her plantation (Mills 1981: 71). Alternatively, she may have simply borrowed enslaved labourers from Metoyer, with whom cordial relations appear to have been maintained: extant records indicate that she was farming tobacco and shipping it down river to New Orleans in conjunction with Pierre Metoyer in 1792 (Mills, G. 1977: 30). Eventually, she was to own 12 to 13 slaves over the three decades she ran her plantation, including one adult of Kissi origin, two adults of Kongo origin, and their nine Louisiana-born children (MacDonald et al. 2006a). By 1806 Coincoin apparently had retired from farming and turned over her 67 acres to her newly freed son, Pierre Metoyer, Jr. (Mills 2009: 22). In 1816 Coincoin settled the rest of her estate, principally her slaves, via property transfers to her children and sold her plantation. From (C) Antiquity Publications Ltd. 
an archaeological perspective, we thus are examining the material and architectural remains of a working plantation occupied over a 30 year span by some 13 to 24 people-counting Coincoin, all her known slaves, and some of Coincoin's children.

In 2001 we began investigations at Coincoin's plantation, our initial fieldwork focusing on locating her original dwelling (MacDonald et al. 2006a). In particular we wished to test competing hypotheses concerning a standing structure on the property claimed by local tradition to have been Coincoin's house, but re-assessed in a National Park Service Historic American Buildings Survey (2001) as a later structure built $c$. 1828-1847, probably as an overseer's house on the subsequent John Prudhomme plantation. Excavations around this structure, as well as the field-walking and geophysical survey of adjacent areas, showed very little eighteenth- to early nineteenth-century activity in proximity to the building. However, an area $c .75 \mathrm{~m}$ north-west of the standing structure revealed extensive artefacts from the late eighteenth/early nineteenth century, which geo-referenced with the Coincoin house as marked on the 1794 survey of the property (Figure 2). Excavations were undertaken in this new core area, as well as across anomalies documented via geophysical survey, primarily with a fluxgate gradiometer and ground-penetrating radar (GPR), between 2005 and 2007. These excavations resulted in a series of structural finds, suggesting the presence of African earthen building technologies at the Coincoin plantation.

\section{Earthen architecture at the Coincoin plantation}

In 1806, a companion journey to the celebrated expedition of Lewis and Clark was launched up the Red River by Freeman and Custis. Their trek took them by the same stretch of river occupied by the Coincoin plantation, and their observations offer a brief, tantalising glimpse of the area:

From the confluence of little river with cane river [sic], to Natchitoches, the land on both banks is generally cultivated... The inhabitants are a mixture of French, Spanish, Indian and Negro blood, the latter often predominating, and live in small cottages on the banks and near the river (Thomas Freeman's journal, 1806 [Flores 1984]).

But, what were these small cottages like? Enigmatically, Maes in his 1794 survey of the property marks Coincoin's house as a mere intersection of four lines in contrast to more detailed sketches of French Creole houses surveyed in the same year along the same stretch of river (Figure 2). Did this imply that there was something unconventional about this dwelling that he felt unable to render, was its humbleness deemed unworthy of representation, or was he simply in a rush?

The architecture of colonial Louisiana has been well documented, with several buildings from the period still extant in Natchitoches Parish (Wells 1973; Edwards 1994, 2002, 2006; Maygarden 2006). Dwellings commonly documented in late eighteenth-century north-western Louisiana took three forms:

- cabanes or maisons: wooden cabins or houses anchored to the ground with widely spaced posts, sheathed with a frame of vertical wooden planks which were nailed-on, not

(C) Antiquity Publications Ltd. 


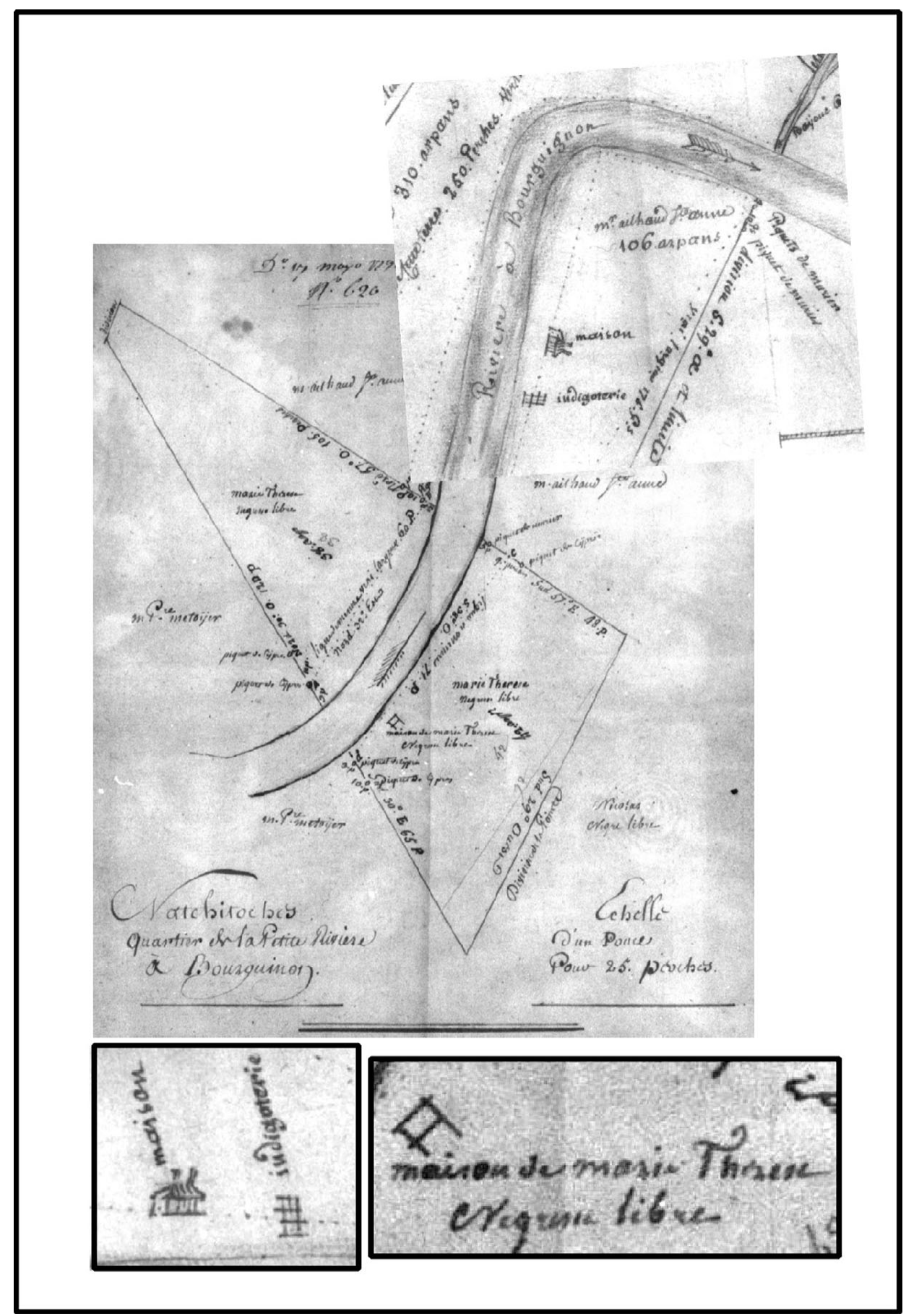

Figure 2. Detail of 1794 survey plans by Pierre Maes, who arrived at the frontier in 1793. It shows the adjoining Coincoin and Ailhaud de St Anne properties (the latter being inset top right). Notice the detailed sketch with two chimneys of the Ailhaud de St Anne dwelling compared to the box-like rendering of the Coincoin house (c) Northwestern State University of Louisiana, Watson Memorial Library, Cammie G. Henry Research Center, Map Collection, Maes folder).

(C) Antiquity Publications Ltd. 
embedded in the ground. Less frequently, these relatively humble dwellings might be covered with bousillage (mud plaster) panels.

- maisons poteaux en terre: houses with a tightly spaced series of posts sunk into the earth, between which was lathe (barreaux) covered by mud plaster, tempered with moss or animal hair (bousillage).

- maisons poteaux sur solle: houses built upon cypress sills, which were raised well above ground level by cypress, stone, or brick piers, and with a latticework of posts and beams holding between them barreaux and bousillage walls.

The rarest of these appears to have been the poteaux en terre model, with Marchand (1943: 85-92) indicating that only one-fifth of colonial examples documented from legal papers were of this form. The poteaux sur solle category is thought to be the most typical and numerous of late eighteenth-century Creole-built forms in the Natchitoches region, initially constructed as two or three room modules and then, with time and increased prosperity, augmented with additional end or back rooms (Wells 1973; Edwards 1994). Yet, most of the architectural remains excavated at the Coincoin plantation differ from these, possessing unique features potentially linked to the fact that Coincoin and all of her household were either native Africans or of African descent.

\section{The Coincoin dwelling area}

Excavations on the house site began in 2005 guided by the traces of an extensive midden filled depression, which was being eroded by tilling on the contemporary hayfield that covers the site. This feature proved to be a $25 \mathrm{~cm}$-deep, roughly circular pit of $c .3 \mathrm{~m}$ in diameter. The midden was replete with domestic debris, including abundant bone (pig, cattle, chicken and wild fauna-particularly terrapins), pottery and charcoal. Of the 15 nails from this feature intact enough to allow identification, all are types that predate 1810 (Edwards \& Wells 1993). The 773 pottery vessel fragments recovered from the pit support the nail chronology. More than a third of the sherds, $43.6 \%(n=337)$, are colonoware, a pottery type largely absent from Cane River plantations post-dating the 1830s (Morgan \& MacDonald 2011). Another 51\% are wares that also were in production only prior to or during the life of Coincoin's plantation. The most numerous examples include English creamwares $(25.1 \%)$ and pearlwares $(12.4 \%)$. These were produced, respectively, between c. 1760 and 1810 and between c. 1780 and 1830 (Hume 1969), although Dawdy (2000: 116-17) cautions that neither were universally available in Louisiana until after the Spanish lifted a trade embargo in the 1790s. The next most common class of pottery found in the pit comprised European tin-glazed wares, especially the French faience type Rouen Plain (12.4\%). French faience formed the primary tableware of the colony until more fashionable and sturdy English creamwares and pearlwares became available.

In the midden locale we also uncovered a total of nine posts that formed portions of two sides of a structure (Figure 3). The holes do not cut through the midden pit, rather, midden debris has in-filled the postholes once the posts themselves were pulled, indicating that the structure immediately pre-dates the midden's formation. A lack of any associated clay collapse or melt and the seemingly temporary nature of this building, given the pulled

(C) Antiquity Publications Ltd. 


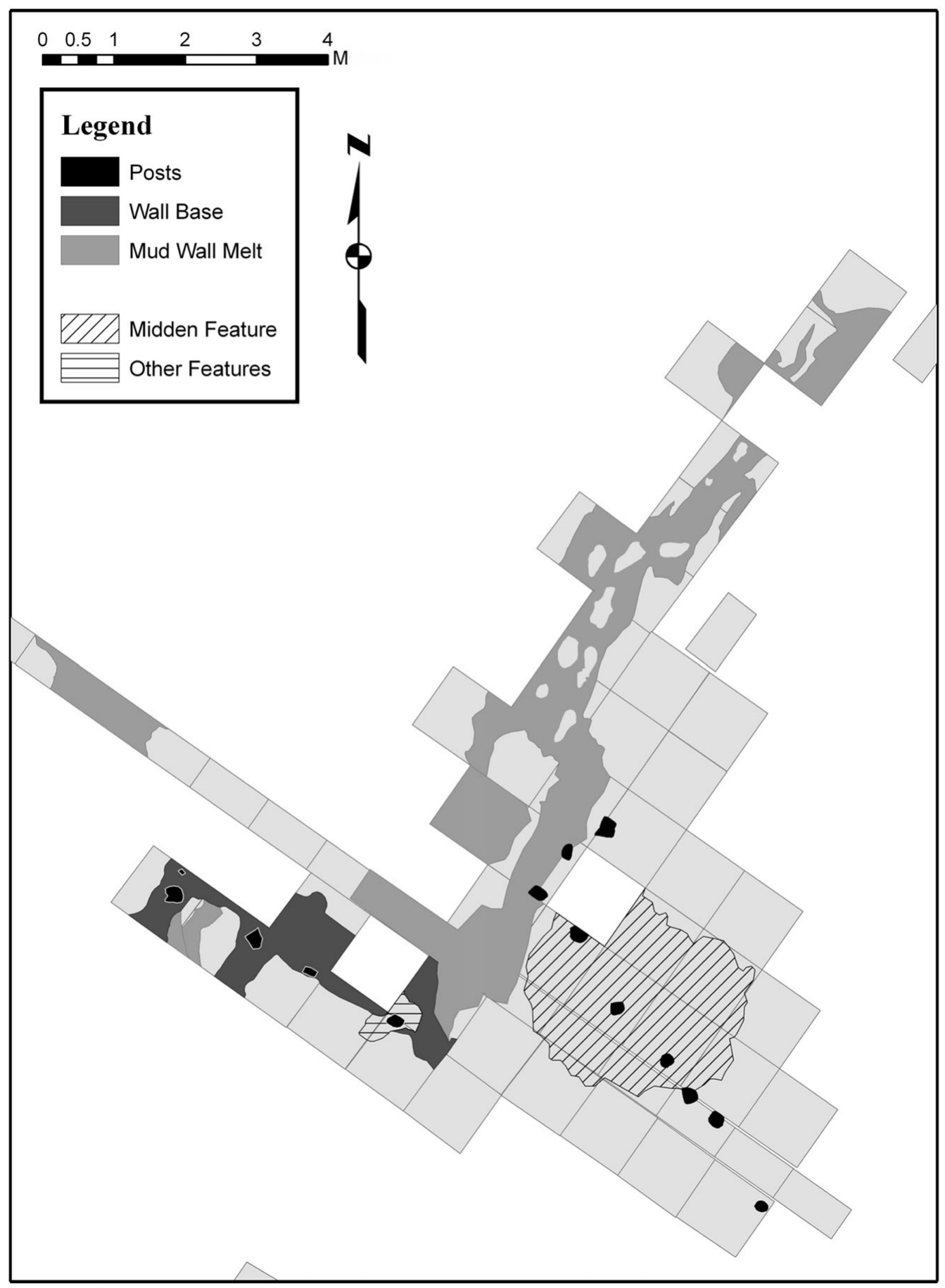

Figure 3. Plan of the main Coincoin dwelling area showing areas of mud melt, earthen foundations and postholes.

(C) Antiquity Publications Ltd. 
posts, implies that it was a plank-walled cabane or maison, the French colonial equivalent of a log cabin (Wells 1973: 15-16, 58-62).

North of the posts and midden pit we defined a linear zone of relatively hard clay, surrounded by a natural silty-loam matrix. This feature was initially attributed either to wall collapse or annual rainy season wall 'melt' (i.e. wash) from an earthen structure. Such mud melt and its archaeological visibility have been documented experimentally by R.J. McIntosh (1974, 1977). We took this melt to derive from a bousillage construction typical for this time period and region. As we found no post features in association with the wall collapse, we hypothesised that this second structure was of poteaux sur solle (post-on-sill) construction, rather than a poteaux en terre (post-in-ground) structure. It also was apparent that the mud melt collapsed over and buried the post features left by the post-in-earth structure, which implies that this second building post-dates the initial cabin.

We interpret the construction sequence as follows. After Marie-Thérèse Coincoin was obliged to leave the home of Pierre Metoyer and move onto this neighbouring 'gifted' property in 1787, some initial dwelling had to be assembled in relative haste. Thus, a plank-walled maison, one of the simplest and least expensive types of local building (Wells 1973), was constructed. A larger structure was built subsequently when time and labour permitted. Sometime after the new earthen construction was complete, the timber cabin was dismantled and its vertical elements were pulled from the ground. Finally, an organic midden reflective of residential life quickly formed, and was shallowly cut into the area formerly occupied by the cabin. This midden remained active long enough for rain and erosion sequences to create thin, sterile micro-layers within it.

In our final season at the site (in 2007) we were able to reach a better understanding of the larger structure. Previously, we had assumed it to be a typical poteaux sur solle structure-the region's dominant eighteenth-century house form. However, as a precautionary measure, we chose to dig through the mud collapse at the west end of the structure revealing, c. $50 \mathrm{~cm}$ below the current ground surface, the sharply demarcated outlines of rammed earth foundations for three wall segments (Figure 3). One wall stump was approximately $5 \mathrm{~m}$ in length and ran perpendicular to the longer wall line; the cross-section of this north-south wall measured $85 \mathrm{~cm}$ wide. The two east-west wall segments were only about $45 \mathrm{~cm}$ in width, and set parallel to each other, about $1 \mathrm{~m}$ apart. They ran perpendicular to the house's short axis and appeared to be a small appendage to the structure. Although incompletely excavated, we believe that these thinner wall bases outline a chimney hearth. Chimneys in colonial Natchitoches were built of bousillage and "most houses had but one chimney which was placed on an end wall even though the house had two or three rooms" (Wells 1973: 32-33). Such chimneys would have an earthen hearth base which was separate from the bousillage chimney stack that could be pushed away from the house if its wooden elements should catch fire. We found no clear burning or charcoal associated with this foundation, but the hard-fired hearth it supported would have been some distance above it—within the house.

What is distinctive about these wall foundations is that their support posts, situated $90-110 \mathrm{~cm}$ apart, are too widely spaced to support bousillage as a poteaux en terre structure would. Indeed, gaps between posts at the extant poteaux en terre Badin Roque house, coeval with and less than $10 \mathrm{~km}$ from the Coincoin plantation, vary between only 26 and $48 \mathrm{~cm}$.

(C) Antiquity Publications Ltd. 
This form of 'close-studding' was common to colonial (and medieval) French architecture (Edwards 2006: 262-63). What we had encountered was either a wide clay foundation upon which a wooden sill was placed or more likely the wide wall stumps characteristic of a rammed earth structure.

Geo-referencing this structure with the 1794 property map via GIS matches the orientation and approximate dimensions of the structure surveyed by Maes. Indeed, in our excavations we were able to trace the collapsed wall material far enough to provide a reasonably solid estimate of the orientation and dimensions of the structure. It appears to have been approximately $12 \mathrm{~m}$ in width (excluding the putative chimney hearth base) with a depth of $6 \mathrm{~m}$. Colonial legal documents place the average dimensions of dwellings constructed in Natchitoches between 1795 and 1799 at 30 French pieds (width) and 18.6 French pieds (depth), based on 11 registered examples (Wells 1973: tab. 7). This equates to $9.73 \times 6.03 \mathrm{~m}$ and would make the primary Coincoin dwelling of greater than average width, but average depth, for its time. Such dimensions would suggest a three-room base module dwelling, a core colonial-era Louisiana-Caribbean built form described by Edwards (1994). Structures of this type usually had a large central room with two smaller flanking rooms.

Overall the Coincoin house is a mixture of features. The presence of a chimney stack on the western wall is a strongly French colonial feature absent in African dwellings. It is not clear whether the house would have had a shaded veranda, common to Louisiana Creole cottages, but no appropriate postholes or footings were encountered. Its strong earthen component and wide studding, however, attest to a form of building as yet unknown in French colonial architecture. In its outline it broadly resembles the French colonial dwellings its owner would have grown up around, but it incorporates novel features which are as yet without parallel regionally.

\section{The earthen enclosure wall}

While excavating a geophysical anomaly $c .50 \mathrm{~m}$ north-east of the Coincoin dwelling area we found the base of an earthen wall, of approximately $40 \mathrm{~cm}$ in thickness. At uneven intervals along this wall we found traces of embedded rectilinear timber supports (Figure 4). Three of these appear as thin slots, as if for boards, another two are larger holes for more standard posts. At first we believed it to be another rammed earth house wall, which would have been remarkable enough. But we found that it continued in a straight line at uniform depths over a length of at least $51 \mathrm{~m}$. It appeared we were looking not at a house, but a boundary wall. We sectioned the wall and found that it was an earthen wall stump lying within a shallow ( $15 \mathrm{~cm}$-deep) foundation trench that cut through alternating waterborne clays and silts from the adjacent river (Figure 5). The stump of the wall itself was dotted with microartefacts including ash, lime, colonoware fragments, shell, etc. . We also encountered a $1 \mathrm{~m}$-diameter clay pit, of $80 \mathrm{~cm}$ depth, directly to the north of our wall alignment. The pit was partially filled with the same clay and microartefact matrix visible in the wall base. GPR survey data increased our surprise. The faint line of our wall trench, dotted with these pits at regular c. $5 \mathrm{~m}$ intervals, appeared to follow an alignment at least $70 \mathrm{~m}$ in length (Figure 6). These pits therefore appear to have been both borrow and mixing pits for the mud solution used in the

(C) Antiquity Publications Ltd. 


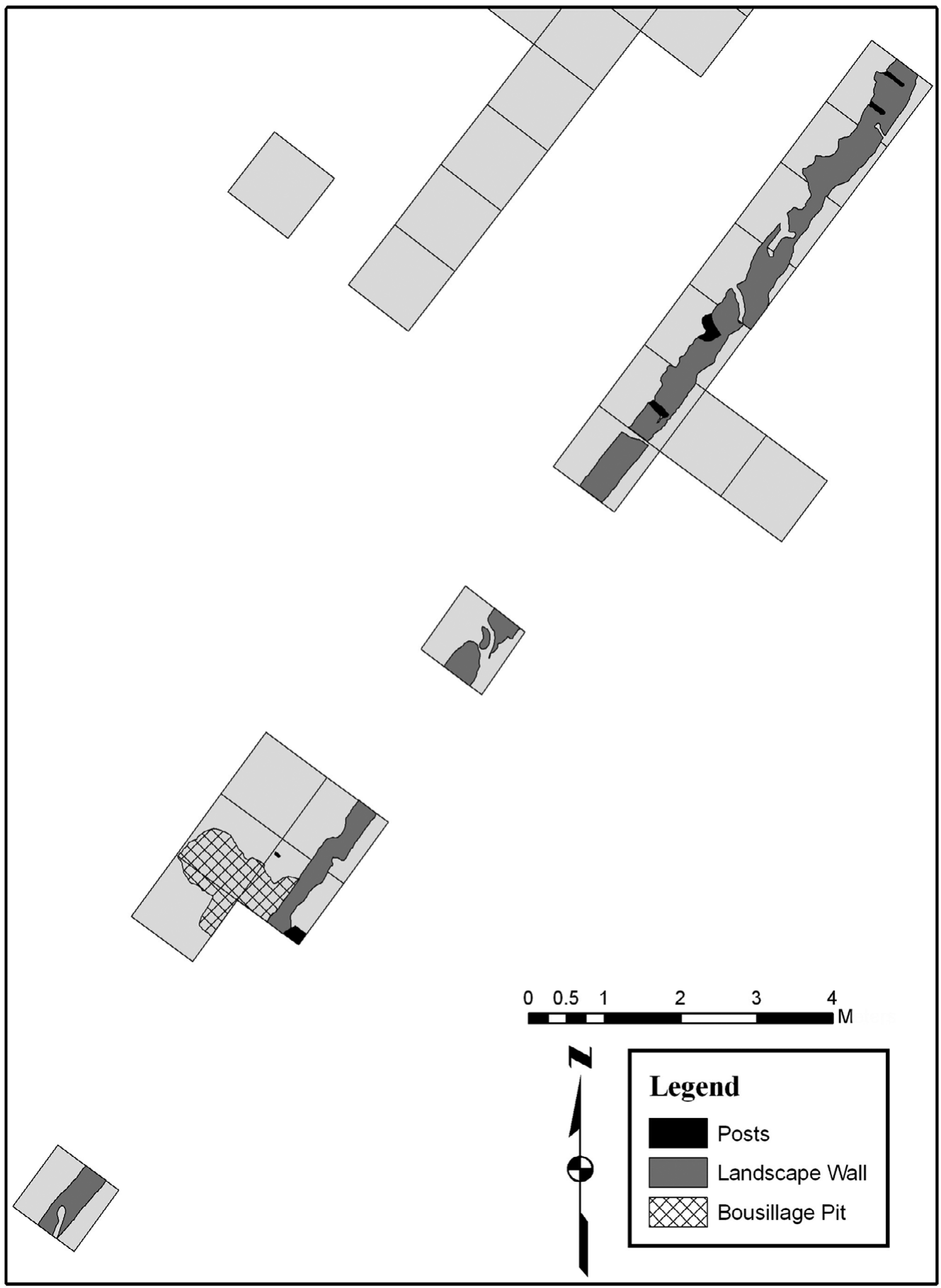

ปี

Figure 4. Plan of a portion of the excavated earthen boundary wall in detail showing inset wooden supports.

(C) Antiquity Publications Ltd. 


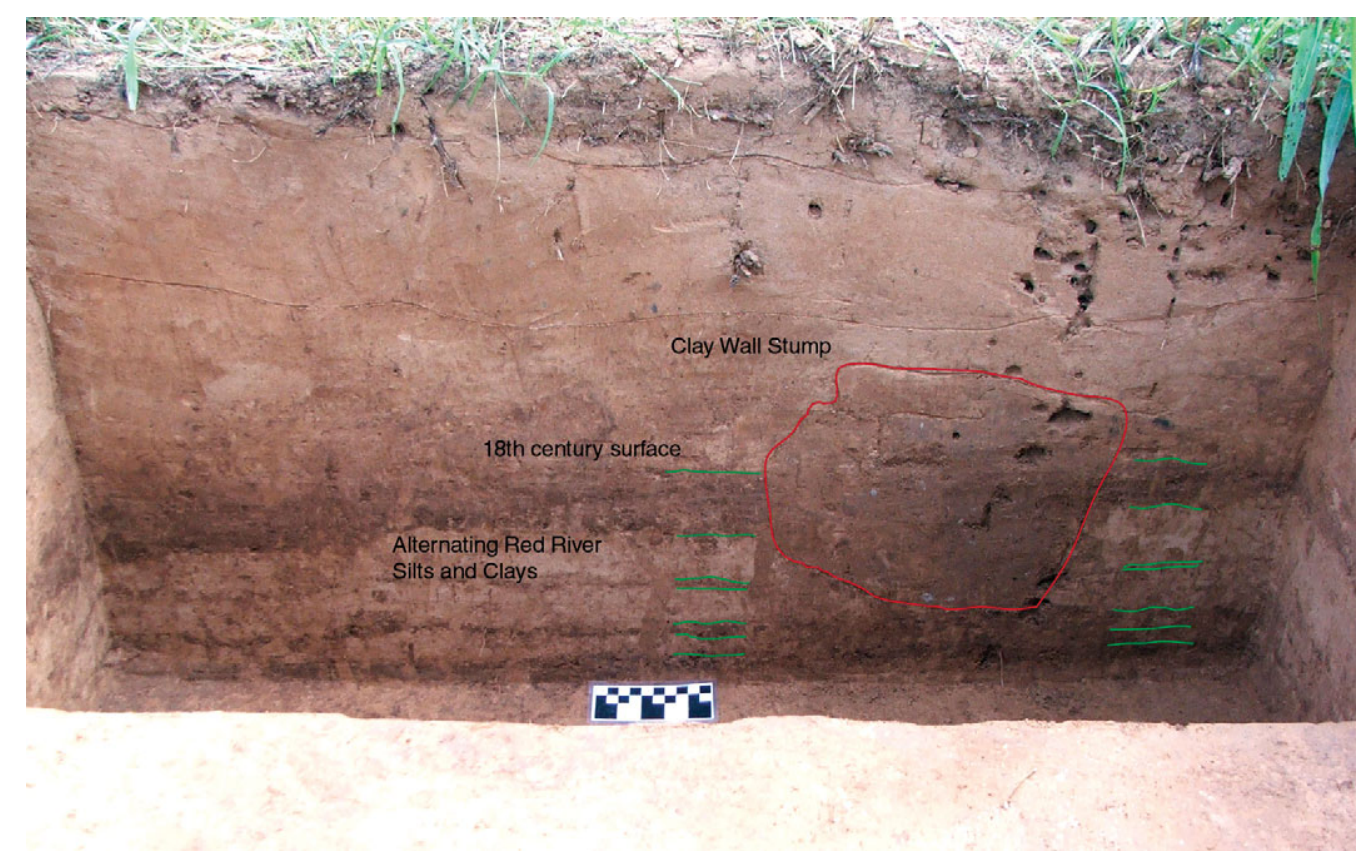

Figure 5. Section of earthen boundary wall at Unit M1 (eastern profile).

adjacent wall. The earthen boundary wall thus appears to have been isolating a $20 \mathrm{~m}$-wide strip of riverfront land, perhaps along the entire river frontage of the Coincoin property.

\section{Discussion: how unique are the Coincoin structures?}

The architectural forms encountered by our excavations at the Coincoin plantation, while featuring certain earthen technological aspects that appear strongly African, must also be understood as being part of a broader process of creolisation, or cultural syncretism which existed throughout the colonial New World (see Stewart 2007). Composite earthen construction, termed 'earthfast' in the architectural literature, is usually a 50:50 ratio of earth to timber elements and was an everyday phenomenon throughout the colonial Americas. Remarkably, it is largely forgotten in the popular imagination of today, in favour of the ' $\log$ cabin.' As Edwards (2006: 265) notes,

In the New World, earthfast construction was almost universal in the seventeenth and early eighteenth centuries, particularly on the frontiers. Thatched, post-in-theground structures using round poles for support of the walls were described as 'in the Indian style' by the French voyageurs, while better built earthfast structures composed of hewn timber posts or planks were said to have been built in the French fashion.

The element of the Coincoin dwelling that makes it unique is that it appears to use less timber, and was thus more sparsely studded, than any documented Creolised forms. Additionally, its wooden posts were placed at the margins of walls, or embedded within them,

(C) Antiquity Publications Ltd. 


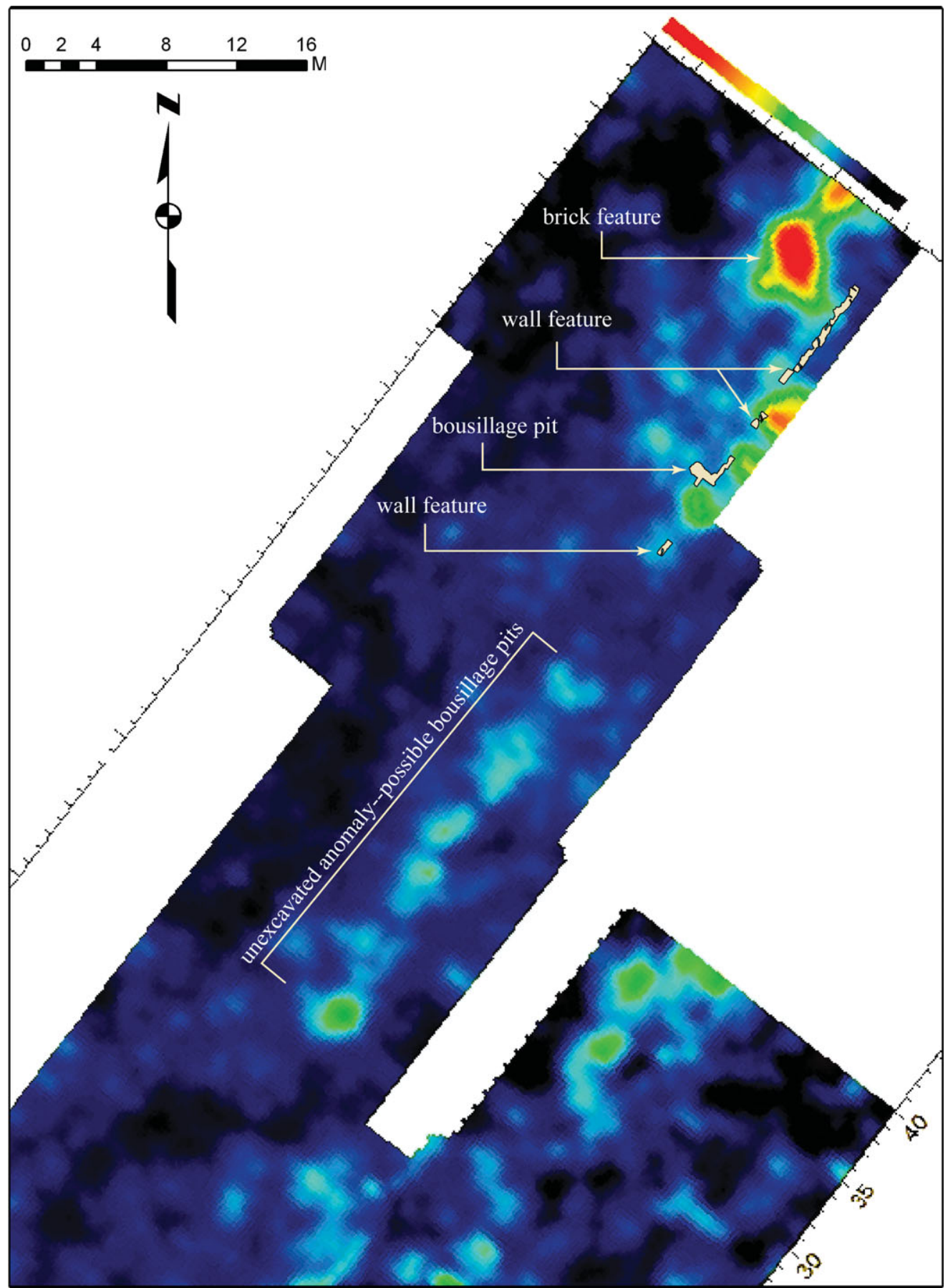

ปี

Figure 6. Ground-penetrating radar survey of the property showing probable borrow pits along the line of the earthen boundary wall.

C) Antiquity Publications Ltd. 


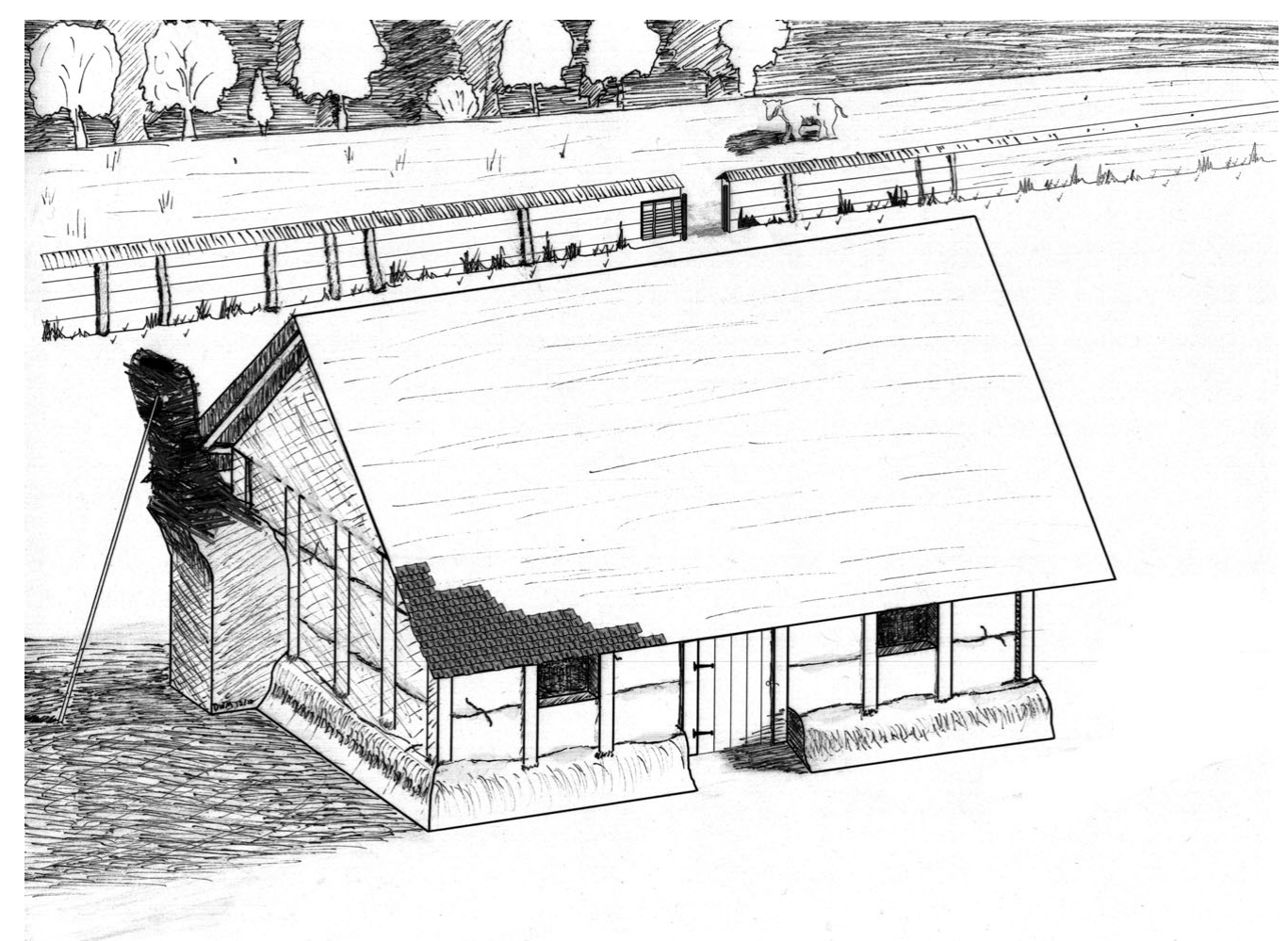

Figure 7. Scale reconstruction of the main Coincoin dwelling and earthen boundary wall c. 1794 .

rather than traversing them. This is reminiscent of some West African rectilinear, rammed earth traditions, where timber supports are widely spaced (e.g. Denyer 1978: fig.116). Such forms were traditionally common amongst peoples known today as the Igbo and Yoruba of Nigeria, but also occur further west in Benin, Togo and Ghana (Denyer 1978: 139). Then again, the apparent ground plan of the principal dwelling equates well with 'Creole Cottages' known throughout the New World French colonies. Edwards $(1994,2002)$ has argued that such built forms are the result of a syncretic combination of Iberian and African influences, adapted to the early settlements of the Caribbean and subsequently transmitted from the French Caribbean to the American South. Creole buildings are thus not the invention of any singular group of Louisiana settlers, but rather a cultural compromise, acceptable to French colonists and familiar in form and composition to the enslaved Africans who were, by and large, their builders.

While Coincoin's plantation structures may, or may not, have seemed out of place beside neighbouring French plantations, depending on their rooflines and surface treatment (the visibility of individual earthen courses, whitewashing, etc. ..), the long rammed earth wall north of Coincoin's principal dwelling shows an African-style construction thus far unique in Louisiana (Figure 7). We believe that this boundary wall, which runs parallel to Cane River, served as a livestock barrier. We know that Coincoin had an economic interest in cattle, because Mills (2009: 14) has pointed out that before completion of her 1794 land (C) Antiquity Publications Ltd. 
patent Coincoin sought, and secured, additional land for cattle grazing along Old River. Our own local inquiries indicate that such barriers were used in contemporary memory to control livestock, which were fenced in on the verdant bank with free access to the river for water. Indeed, there is evidence of at least two more recent boundaries within metres of the earthen wall, all in parallel.

The use of earthen walled enclosures, while common in West Africa, has been up until now undocumented in the United States. Given the dearth of historical documentation of such structures, large-scale excavations of colonial-era African sites in the Americas may provide us with our only window on such built forms prior to 1800. In this particular case, we may be viewing an African solution to a New World problem: an earthen wall to pen livestock would cost nothing apart from tools and labour, while timber for a large fenced enclosure would entail comparative economic sacrifice. Regarding problems of maintenance for an 'open' earthen wall in a high rainfall region, one may invoke the possibility of a wood or thatch covering overlying the top of the wall to impede erosion, as is the case in southern Nigerian traditions (Dmochowski 1990: 12).

The principal dwelling and the boundary walls at the Coincoin plantation appear to have been made out of rammed or coursed earth, and not from bousillage or mud-brick. In Africa, by the colonial era, mud-brick was common along the Sahelian belt, while coursed or rammed earth remained dominant in the more southerly savannah-forest zones of West Africa (Denyer 1978; Prussin 1986). Further south, in Central Africa, 'Kongo' (or Bakongo) peoples had no indigenous tradition of earthen architecture, building thatched rectilinear structures in a basketwork fashion with stakes interwoven with stout dried vines (Balandier 1968: 139-52). Some later authorities such as de Lucques (writing around 1705; Cuvelier 1953) mention the occasional use of mud plaster over wattling due to Portuguese influence, but no mention is made of rammed earth architecture. This would appear to eliminate Coincoin's Kongo slaves from consideration as the authors of this architecture. Likewise, Coincoin's Kissi slave (Harry), coming from southern Guinea where earthen architecture was extant, was not acquired by Coincoin until after 1810, when there is reason to believe that construction on the plantation would have ceased (Mills 2009, E. Shown Mills pers. comm.). One is therefore obliged to consider the possibility that the builders of these structures may have been borrowed from a neighbouring plantation, most particularly the adjoining property of the father of Coincoin's children, Pierre Metoyer.

Notably, Metoyer's slaves included Christophe and Jacques both of 'Moco' (or Moko) nation, and both aged around 30 at their baptisms in 1795 (records 2770 and 2771, Mills, E. 1977). Critically, these two individuals were of an appropriate age and present within view of the Coincoin property at the right time to have suggested or planned the building of the structures in question.

The Moko 'nation name' was documented from individuals enslaved in the Bight of Biafra and is a relatively rare self-identification for eighteenth-century Louisiana slaves. Hall (2005: 43-44) notes only 82 such instances as compared to, for example, 524 Igbo. Today, there is a tendency to equate 'Moko' with Efik/ Ibibio peoples, near neighbours of the modern Igbo in the Nigerian Cross Rivers region (e.g. Hall 2005). However, some historians such as Thornton (1998: xxiv) have classed the sixteenth-century 'Moco' as an Igbo sub-group, and 


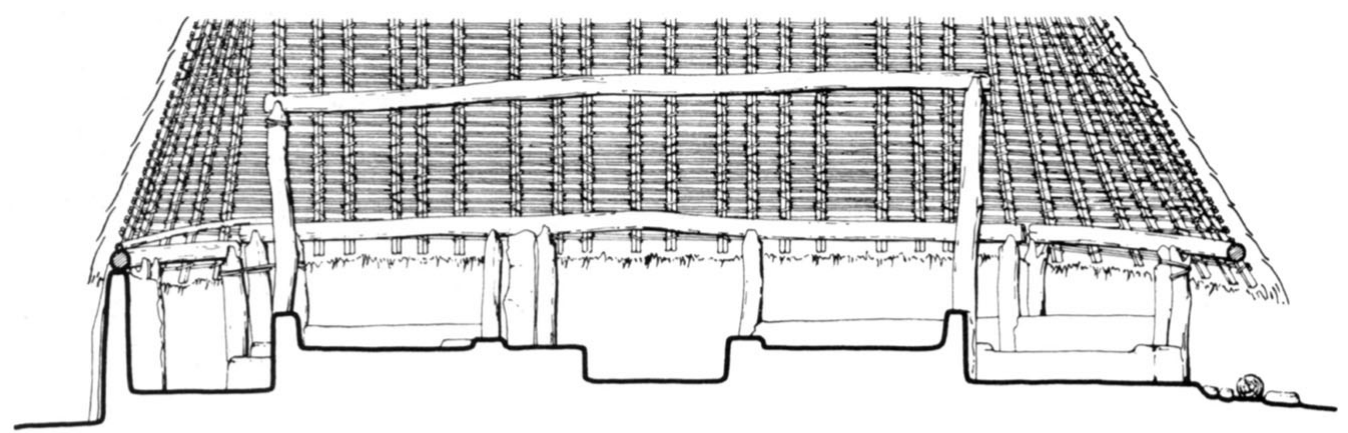

\section{$3 \mathrm{~m}$}

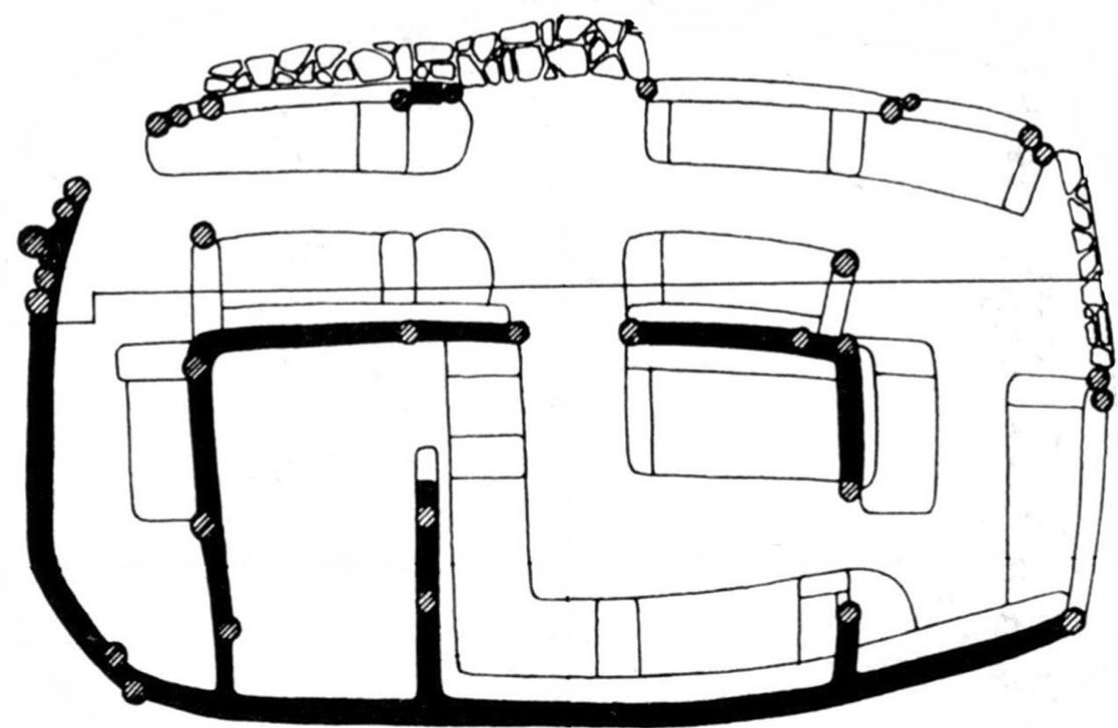

Figure 8. Architectural plan of typical southern Igbo family dwelling (Ada section), showing raised earthen footings and the placement of support posts. The central line on the horizontal plan shows the location of the vertical cross-section (after Dmochowski 1990: figs 186 and 189).

G.I. Jones (1963: 36) identified the eighteenth-century 'province of Moko' as being part of southern Igbo political associations.

Regardless, the Efik/Ibibio and Igbo are all traditionally builders of rectilinear earthen structures with a timber core (Figure 8; Parkinson 1907; Ekong 1983; Dmochowski 1990), and it is interesting to note parallels between south-eastern Nigerian traditions and our (C) Antiquity Publications Ltd. 
findings at Coincoin's plantation. With the borrow pits along the boundary wall in mind, the following observations are striking:

The earth was dug around the middle of the wet season from pits near the building site. Removal of the topsoil revealed the red clay beneath. This was broken into small lumps with hoes and left in the pit until the rain came... Loam was occasionally prepared by mixing together different materials (Dmochowski 1990: 10).

This 'tempering' of wall materials and the proximity of borrow pits coincide well with our earthen boundary wall. Likewise, in Igbo regional traditions, wall foundation-trench depths vary between 15 and $40 \mathrm{~cm}$ in depth, and most wall thicknesses vary between 30 and $40 \mathrm{~cm}$ (Dmochowski 1990: 11). This is well within the ranges documented at the Coincoin plantation with the exception of the thick foundation wall stump at the west end of the principal dwelling. Yet this, too, is within the scope of south-eastern Nigerian traditions, where broader earthen foundations of principal walls can form part of internal earthen benches or shelves (Dmochowski 1990: 27).

Finally, there are parallels regarding roof support post technology:

The posts supporting the purlins could be fixed clear of the walls, either outside, or, infrequently, inside ... More commonly they were deeply embedded in the walls, thus increasing their stability (Dmochowski 1990: 15).

Given the foregoing, Christophe and Jacques, as south-eastern Nigerian-born slaves of the adjoining Metoyer plantation, would certainly seem plausible agents in the construction of the Coincoin structures; although other as yet unidentified African-born members of the Metoyer household, or other nearby plantations, might also have been involved. The documented economic collaboration of Coincoin and Metoyer in 1792, years after their domestic alliance ended, and the adjoining nature of their properties, would make such loans of labour appear reasonable (Mills, G. 1977: 30).

In North America outside of French colonial Louisiana the only other published evidence for African forms of building comes from the eighteenth-century Curriboo and Yaughan plantations in South Carolina (Wheaton \& Garrow 1985; Ferguson 1992: 63-82; Wheaton 2002). Several structures documented at these plantations appear to be of rammed earth with roof support posts, showing strong parallels to the principal dwelling at the Coincoin plantation. One example in particular shows an earthen two-room structure with external roof support posts and additional posts fully enclosed within the wall fabric (Ferguson 1992: fig. 46). Again, like our boundary wall, the earthen walls at Curriboo and Yaughan were set within 24 to $45 \mathrm{~cm}$-wide foundation trenches (Wheaton 2002: 36). However, the spacing between posts in all of the Curriboo and Yaughan plantation structures appears to have varied widely, sometimes approaching 'close-studding.'

\section{Conclusion}

Our survey and excavation of the Coincoin property presents us with a building sequence for the 1787-1816 plantation including an unusual main dwelling incorporating African technological elements. Additionally, our findings include an earthen boundary wall—which 
to our knowledge is as yet unique in colonial Louisiana. Given the rarity of information concerning housing generated by persons of African descent in the Americas, these data from the Coincoin plantation reveal aspects of forgotten architectural traditions in colonial Louisiana and illustrate the process of creolisation.

The intangible element shared by Coincoin, Yaughan and Curiboo is that all were the result of first or second generation Africans having sufficient agency to make dwellings of their own choosing. Although such idiosyncratic structures are as yet only documented in three eighteenth-century contexts, this may still hint at a meaningful trend. Like the gradual disappearance of colonoware in the first half of the nineteenth century (cf. Singleton 1988; Morgan \& MacDonald 2011), the changing African-American cultural mosaic after the 1810 s shows communities with fewer first generation slaves, more strongly affected by the regimentation and intolerance of Euro-American communities. This transition is a key point of inquiry for Diaspora studies, and it is before this time that we are most liable to encounter fresh information and not a few surprises. Structures like those from Coincoin, Curriboo and Yaughan plantations open a window on colonial American built landscapes that are vastly different from those typically envisaged.

\section{Acknowledgements}

This research was funded by grants from the UK Arts and Humanities Research Council and the US National Endowment for the Humanities. We wish to acknowledge all of those who worked with us in the 2005 to 2007 excavations, but most particularly our colleague Fiona Handley, the project's Assistant Director, and Katherine Derrett for her research on the Badin Roque House.

\section{References}

Balandier, G. 1968. Daily life in the Kingdom of the Kongo: from the sixteenth to the eighteenth century. London: Allen \& Unwin.

Cuvelier, J. 1953. Relations sur le Congo du père Laurent de Lucques (1700-1717). Brussels: Institut Royal Colonial Belge.

DAWDY, S.L. 2000. Understanding cultural change through the vernacular: creolization in Louisiana. Historical Archaeology 34: 107-123.

DENYER, S. 1978. African traditional architecture: an historical and geographical perspective. New York: Africana.

DMOcHowsKi, Z.R. 1990. An introduction to Nigerian traditional architecture. Volume 3: south-eastern Nigeria, the Igbo-speaking areas. London: Ethnographica in association with the National Commission for Museums and Monuments.

EDWARDS, J.D. 1994. The origins of Creole architecture. Winterthur Portfolio 29: 155-89.

-2002 . Vernacular vision: the gallery and our Africanized architectural landscape, in J.E. Hankins \& S. Maklansky (ed.) Raised to the trade: Creole building arts of New Orleans: 61-94. New Orleans (LA): New Orleans Museum of Art.
- 2006. Creole architecture: a comparative study of Upper and Lower Louisiana and Saint Dominigue. International Journal of Historical Archaeology 10: 241-71.

EDWARDS, J. D. \& T. Wells. 1993. Historic Louisiana nails: aids to the dating of old buildings (Fred B.

Kniffen Cultural Resources Laboratory Monograph Series 2). Baton Rouge (LA): Geoscience Publication, Louisiana State University.

EKONG, E.E. 1983. Sociology of the Ibibio: a study of social organization and change. Calabar: Scholars Press.

FERGUSON, L. 1992. Uncommon ground: archaeology and early African America, 1650-1800. Washington (DC): Smithsonian Institution Press.

FLORES, D.L. (ed.) 1984. Southern counterpart to Lewis \& Clark: the Freeman \& Custis expedition of 1806. Norman (OK): University of Oklahoma Press.

HALL, G.M. 2005. Slavery and African ethnicities in the Americas: restoring the links. Chapel Hill (NC): University of North Carolina Press.

Hume, I.N. 1969. A guide to artifacts of colonial America. New York: Alfred A. Knopf.

(C) Antiquity Publications Ltd. 


\section{Kevin C. MacDonald \& David W. Morgan}

JONES, G.I. 1963. The trading states of the oil rivers: a study of political development in Eastern Nigeria. London: Oxford University Press.

MacDonald, K.C., D.W. Morgan \& F.J.L. Handley. 2006a. The Cane River African Diaspora Archaeological Project: prospectus and initial results, in J.B. Haviser \& K.C. MacDonald (ed.) African re-genesis: confronting social issues in the diaspora: 123-44. London: UCL Press.

MacDonald, K.C., D.W. Morgan, F.J.L. Handley, A. LEE \& E. MORLEY. 2006b. The archaeology of local myths and heritage tourism: the case of Cane River's Melrose plantation, in R. Layton, S. Shennan \& P. Stone (ed.) A future for archaeology: 127-42. London: UCL Press/Cavendish.

MarChand, B.D. 1943. Acadian exiles in the Golden Coast of Louisiana. Donaldsville (LA): Published by the Author.

MAYGARDEN, B.D. 2006. Building in colonial Louisiana: creolization and the survival of French traditions. International Journal of Historical Archaeology 10: 211-39.

McInTOSH, R.J. 1974. Archaeology and mud wall decay in an African village. World Archaeology 6: 154-71.

- 1977. The excavation of mud structures: an experiment from Africa. World Archaeology 9: 185-99.

MiLLS, E.S. 1977. Natchitoches: abstracts of the Catholic church registers of the French and Spanish post of St. Jean Baptiste des Natchitoches in Louisiana: 1729-1803. New Orleans (LA): Polyanthos.

- 1981. Natchitoches colonials: censuses, military rolls, and tax lists 1722-1803. Chicago (IL): Adams Press.

- 2009. Marie Thérèse Coincoin (1742-1816): Cane River slave, slaveowner, and paradox, in J. Allured \& J. Gentry (ed.) Louisiana women: their lives and times: 10-29. Athens (GA): University of Georgia Press.

Mills, G.B. 1977. The forgotten people: Cane River's Creoles of color. Baton Rouge (LA): Louisiana State University Press.

Morgan, D.W. \& K.C. MaCDONALD. 2011. Colonoware in western colonial Louisiana: makers and meaning, in K. Kelly \& M. Hardy (ed.) French colonial archaeology in the Southeast and the Caribbean: 117-51. Gainesville (FL): University of Florida Press.
National Park Service Historic American Buildings Survey. 2001. LA-1295: Coincoin-Prudhomme House (Maison de Marie Therese). Unpublished manuscript on file at the Cane River National Heritage Area, Natchitoches. Available at: http://www.nps.gov/history/hdp/samples/HABS/ coincoin/history.pdf (accessed 24 May 2011)

PARKInson, J. 1907. A note on the Efik and Ekoi tribes of the Eastern Province of Southern Nigeria. Journal of the Royal Anthropological Institute 37: 261-67.

Prussin, L. 1986. Hatumere: Islamic design in West Africa. Berkeley (CA): University of California Press.

Singleton, T.A. 1988. An archaeological framework for slavery and emancipation, $1740-1880$, in M.P. Leone \& P.B. Potter, Jr. (ed.) The recovery of meaning: historical archaeology in the eastern United States: 345-70. Washington (DC): Smithsonian Institution Press.

Singleton, T.A. \& M.D. Bograd. 1995. The archaeology of the African diaspora in the Americas. Ann Arbor (MI): The Society for Historical Archaeology.

STEWART, C. 2007. Creolization: history, ethnography, theory. Walnut Creek (CA): Left Coast Press.

THORNTON, J. 1998. Africa and Africans in the making of the Atlantic World, 1400-1800. Cambridge: Cambridge University Press.

WELLS, C.M. 1973. Domestic architecture of colonial Natchitoches. Unpublished MA dissertation, Northwestern State University of Louisiana, Natchitoches.

WheAtOn, T.R. 2002. Colonial African American plantation villages, in J.W. Joseph \& J.A. King (ed.) Another's country: archaeological and historical perspectives on cultural interactions in the southern colonies: 30-44. Tuscaloosa (AL): University of Alabama Press.

WheAton, T.R. \& P.H. GARROW. 1985. Acculturation and the archaeological record in the Carolina Lowcountry, in T. Singleton (ed.) The archaeology of slavery and plantation life: 239-59. Orlando (FL): Academic Press.

Received: 21 December 2010; Accepted: 2 May 2011; Revised: 24 May 2011

(C) Antiquity Publications Ltd. 